\title{
INVESTMENT AND CONSUMPTION CHANNELS OF NON KEYNESIAN EFFECTS OF MACROECONOMIC POLICIES. SOME EMPIRICAL STUDIES FOR ROMANIA
}

\author{
Ana ANDREI \\ Bucharest Academy of Economic Studies, Romania \\ ana.andrei@csie.ase.ro \\ Angela GALUPA \\ Bucharest Academy of Economic Studies, Romania \\ angela.galupa@csie.ase.ro \\ Sorina GRAMATOVICI \\ Bucharest Academy of Economic Studies, Romania \\ sorina.gramatovici@csie.ase.ro \\ Nora CHIRITA \\ Bucharest Academy of Economic Studies, Romania \\ nora.chirita@csie.ase.ro \\ Ionut NICA \\ Bucharest Academy of Economic Studies, Romania \\ ionut.nica@csie.ase.ro
}

\begin{abstract}
In this paper we investigate if the fiscal policies changes in Romania can produce non-Keynesian effects. Our approach uses Rzońca and Cizkowicz model to investigate the effect of fiscal impulse on the economic growth rate, on the privat investments rate, and on the private consumption rate. We also compute time-varying coefficients for the Johansson and Johnson consumption function as a state vector of a space state dynamic system, by applying the Kalman filter algorithm.

The consumption function with time-varying coefficients is used to study the effects of fiscal policies on the consumption.
\end{abstract}

Keywords: Keynesian and non-Keynesian effects, consumption channel, investment channel, fiscal impulse, fiscal consolidation

JEL classification: E12, E21, E62, C54

DOI: $10.24818 / \mathrm{ie} 2020.05 .07$

\section{Introduction}

Unlike the traditional Keynesian view, some studies indicate that contractionary economic policy can stimulate short -term economic action.

Most fiscal episodes over the last decades have contributed to the development of theoretical and empirical literature on so-called "non-Keynesian effects of fiscal policies".

The first that considered the possibility of non -Keynesian effects were Giavazzi and Pagano (1990) who studied fiscal consolidations in Denmark (1983-1986) and Ireland (1987-1989) and proved the expansionary effects of this policy. 
Perotti (1996) and Alesina and Perotti (1997) considered that fiscal adjustment can generate non-Keynesian effects, reducing public spending and increasing taxes.

Feldstein (1982) and Drazen (1990) argued that reducing government spending may have an expansionist effect as it indicates a future reduction in taxes and rising expectations on disposal income.

McDermott and Wescott (1996) discussed the possibility of wealth effect generated by fiscal consolidation that can reduce the interest rate. The reduction of interest rate contributes to the increase of the market value of the portfolios held by population and generates corresponding wealth effect of increasing aggregate demand.

Blanchard (1990), Sutherland (1997) and Perotti (1999) proved if the public debt/GDP ratio is high then, a negative shock to public expenditures stimulates consumption and production. Sutherland (1995) demonstrated that with a high debt/GDP ratio, a reduction in taxes can paradoxically lead to the decrease in private consumption. This effect is due to the population expectations that the accrued interests to debt will require the increase of future taxes in order to pay them.

Canale et al (2007) argued that a synchronous and opposite monetary policy as the intervention reaction of the central bank to fiscal consolidation could generate non-Keynesian effects. Therefore, it is necessary to correlate the fiscal and monetary policy.

In contrast, Hemming (2002) and Adagna (2004) pointed out that alternative monetary policies have a relative small effect on the size of short-term fiscal multipliers and thus could not influence expansionary fiscal contractions.

Maria Neicheva (2007) found that the size of the fiscal impulse is the most important factor in the study of non-Keynesian effects.

Tagkalakis (2013) provided evidences of non-Keynesian effects in Greece. He observed that non-Keynesian effects are higher in the case of public spending cuts than in the case of increase taxes.

Alfonso and Silva Leal (2019) estimated the elasticities of private consumption with respect to fiscal instruments for 19 euro area countries during the period 1960-2017. They concluded that an increase in taxes is currently perceived by the population as a future increase in government spending, generating non-Keynesian effects.

The aim of our paper is to check out the channels for non-Keynesian effects of discretionary fiscal policies using statistical data of Romania. In order to complete our study, we extend some of the results of Rzońca and Ciżkowicz (2005) both for investments and consumption models. We also compute the Kalman filter variable coefficients for the consumption function introduced by Johansson and Johnson (2003).

\section{The channels of non-Keynesian effects and the fiscal impulse computation}

Manny theoretical studies concern the channels that could generate non-Keynesian effects in an economy. The most commonly cited transmission channels of the non-Keynesian effects are the consumption and the investment channels.

The consumption channel main hypothesis is that the fiscal consolidation effect could generate the raise of the personal consumption. This consequence may be due to the expectations, to the wealth effect and also to a substitution effect (Da Costa and Carvalho, 2009). The expectations effect is generated by the fact that the fiscal consolidation will reduce the uncertainty on the future taxes which, as a consequence, will reduce the precautionary savings and therefore will rise the consumption (Feldstein,1982).The wealth effect appears due to the reducing of the interest rate following the fiscal contraction. The transmission mechanism is the rise of market value of bonds which increases the consumption. The substitution effect 
refers to the substitutions between the public consumption which is diminished as a result of fiscal consolidation and the private consumption (Giavazzi and Pagano, 1990).

The investment channel is based on the assumption that fiscal consolidation generally results in the increasing of the private investments that "is too robust to be attributed to the crowdingin effect only" (Alesina et al., 1998).

This channel has two major sources: the credibility/interest rate effect described by Ardagna (1998) and the labor market effect introduced by Blanchard and Perotti (1999) and (2002).

The economic mechanism of the credibility/interest rate effect is simple. During the fiscal consolidations, the interest rate decreases due to the reduction of the government borrowing, and generates the increase of the private investment.

The labor/market effect consists in a different mechanism. The reduction of the government expenditures generates the reductions of the wage claims which stimulate the employment, investments and economic growth.

Another interesting problem in the research field of non-Keynesian effects consists in defining and to computing indicators that could measure better the fiscal policy.

There are different and sometimes controversial views in this field. For example, Renee and Janssen (2002) and Wells (1995) proposed the structural fiscal balance as a measure of fiscal policy or also the shifts of IS-LM model.

In some other papers as Blanchard (1993), Blanchard and Perotti (1999) and Blanchard (2000) it is accredited the idea that a simple measure of fiscal policy effects is not able to reflect the second-order effects. It is suggested a macroeconomic global model or a structural vector auto regression model (SVAR) to measure these effects.

Most researchers in the field use as a measure the fiscal balance defined as the difference between the government's current operating revenues and the current operating expenses.

Blanchard (1993) introduced an indicator of discretionary fiscal policy known as the Blanchard Fiscal Impulse (BFI). The (BFI) is defined as the ratio of the primary surplus that could be obtained with the unemployment at the level of previous year to the current GDP, minus the ratio of the value of the primary surplus in the previous year to the GDP in the previous year. The most usual methods for fiscal impulse as resumed by Alesina, Perotti (1995) are the following:

- The primary balance:

- The BFI

$$
\begin{aligned}
& F I=\left(g_{t}-t_{t}\right)-\left(g_{t-1}-t_{t-1}\right) \\
& \quad: F I=\left(g_{t}\left(u_{t-1}\right)-t_{t}\right)-\left(g_{t-1}-t_{t-1}\right) \\
& \quad: F I=\left(\left(G_{t}-T_{t}\right)-\left(G_{t-1}\left(1+\hat{y}_{t}\right)-T_{t-1}\left(1+\hat{y}_{t}\right)\right)\right) / Y_{t-1} \\
& \quad: F I=\left(\left(G_{t}-T_{t}\right)-\left(G_{0}\left(1+\hat{y}_{t}\right)-T_{0}\left(1+\hat{y}_{t}\right)\right)\right) / Y_{t-1}
\end{aligned}
$$

where $G_{t}$ is the total current expenditures plus gross capital accumulation, less interest payments; $T_{t}$ is the total revenue; $g_{t}$ and $t_{t}$ are the same variables but as shares in GDP; $Y_{t}$ is the nominal GDP; $y_{t}$ is the growth rate of nominal GDP; $\hat{y}_{t}$ is the growth rate of nominal potential GDP; $G_{0}$ is the value of $G_{t}$ in the base year, $T_{0}$ represents the revenues in the base year and $u_{t}$ is the actual unemployment rate.

\section{The investment channel modelling}

Andrzej Rzońca and Piotr Ciżkowicz (2005) studied the investments channel of fiscal policies effects and proposed a model that reflects the effect of fiscal impulse on the growth rate of the investments and of the economic growth. 
The effect of fiscal impulse on the economic growth rate is given by the equation:

$$
g d p_{t}=\mu+\delta_{1} g d p_{t-1}+\sum_{k=1}^{2} \beta_{k} i m p_{t-k+1}+\sum_{l=1}^{2} \varphi_{l} \text { reer }_{t-l+1}+\sum_{m=1}^{2} \gamma_{m} c s_{t-m+1}+\varepsilon_{t}
$$

where $g d p_{t}$ is the GDP growth rate; imp is the primary deficit fiscal impulse; reer is the real interest rate; $c s$ is the real exchange rate of national coin to Euro; $\varepsilon$ is the white noise error. Non-Keynesian effects could appear if the government expenditures rise, therefore the fiscal impulse rises and generates a high and persistent crowding-out effect on the private investments. That is, in the above equation, at least one of the coefficients $\beta_{1}, \beta_{2}$ should be negative significant as value.

$$
\begin{aligned}
& g d p_{t}=0.0029+0.9195 g d p_{t-1}-0.1357 \text { reer }_{t-1}-0.0376 \text { reer }_{t}+0.0297 \text { cs }_{t}-0.0018 c s_{t-1}- \\
& -0.0091 \mathrm{imp}_{t}+0.0036 \mathrm{imp}_{t-1}+\varepsilon_{t}
\end{aligned}
$$

We note that the contemporary fiscal impulse is negative and statistical significant but it has a small value so that it could be interpreted rather as crowding out effect of the government expenditures policy.

In the above equation, the delayed fiscal impulse is positive and has also a small value, meaning that the delayed Keynesian effect of fiscal policy is reduced.

The second equation, of the private investments rate, is given by:

$$
\operatorname{rinv}_{t}=\mu+k \operatorname{krinv} v_{t-1}+\sum_{j=1}^{2} \delta_{j} g d p_{t-j+1}+\sum_{k=1}^{2} \beta_{k} i m p_{t-k+1}+\sum_{l=1}^{2} \lambda_{1} \text { aratio }_{t-l+1}+\sum_{m=1}^{2} \gamma_{m} \text { reer }_{t-m+1}+\varepsilon_{t}
$$

where rinv is the private investments rate; aratio is a dummy variable with 1 value if the government expenditures in the fiscal impulse is greater than $50 \%$ and 0 value, otherwise. The computed equation is given below.

$$
\begin{aligned}
& \text { rinv }_{t}=-0.3238+0.0550 \text { rinv }_{t-1}-0.1888 \text { imp }_{t}+0.0475 \text { imp }_{t-1}-0.4493 \text { reer }_{t}-1.0787 \text { reer }_{t-1} \\
& +1.6878 \text { gdp }_{t}+1.0918 g \text { dp }_{t-1}+0.0972 \text { aratio }_{t}+0.0500 \text { aratio }_{t-1}+\varepsilon_{t}
\end{aligned}
$$

In the above equation the contemporary fiscal impulse is negative and statistically significant and it has a value that could suggest the presence of the non-Keynesian effect on private investment.

The dummy variable aratio signifies the magnitude of the influence of the government expenditures on the private investments. We can notice the government expenditures have a significant influence on private investments both in the current period and in the previous period.

The influence of the real interest rate on the private investment rate is negative and significant, as expected.

The descriptive analysis shows that the amplitude of the fiscal impulse is an important factor of influence on the growth rate and on the private investment rate and the fact. Also the fiscal consolidations, especially those made by the reducing of the government expenditures, are usually accompanied by significant increases in output.

\section{The consumption channel modelling}

In order to verify the existence of non-Keynesian effects we employ two models.

The first one, proposed by Johansson and Johnson (2003) is based on a dynamic consumption function with time varying parameters in order to measure the effect of the fiscal policies on the consumption and it is described below. 


$$
\Delta C_{t}=\beta_{0 t}+\beta_{1 t} \Delta Y_{t}+\beta_{2 t} \Delta G_{t}+\varepsilon_{t}
$$

where $\varepsilon_{t}$ is the error, a stochastic process $\varepsilon_{t} \approx N\left(0, \sigma^{2}\right)$ and $\beta_{t}$ follows a random walk with disturbances $v_{t}$ which are normally distributed with zero mean and covariance matrix $\mathrm{Q}$, $v_{t} \approx N(0, Q)$. Therefore, the state variable vector is given by $\beta_{t}^{T}=\left[\beta_{0 t}, \beta_{1 t}, \beta_{2 t}\right]$ and the space state dynamic system is:

$$
\begin{array}{ll}
\Delta C_{t}=\left[\begin{array}{l}
1 \\
\Delta Y_{t} \\
\Delta G_{t}
\end{array}\right]\left[\beta_{0 t}, \beta_{1 t}, \beta_{2 t}\right]+\varepsilon_{t} & \varepsilon_{t}: N\left(0, \sigma_{\varepsilon}^{2}\right) \\
\beta_{t}=\beta_{t-1}+v_{t} & v_{t}: N(0, Q)
\end{array}
$$

The output variable is $y_{t}=\Delta C_{t}$ and the coefficients represent the observable vector $x_{t}=\left[1, \Delta Y_{t}, \Delta G_{t}\right]$.The first equation from (6) is called the measurement equation and it relates the the dependent variable $\Delta C_{t}$ to the observed variables $\left[1, \Delta Y_{t}, \Delta G_{t}\right]^{T}$. The second equationfrom (6) is called the transition equation and it gives the dynamics of the unobserved state variables $\beta_{t}$.

As $x_{t}=\left[1, \Delta Y_{t}, \Delta G_{t}\right]$ and $\Delta C_{t}$ are given, it is easy to determine $\beta_{t}^{T}=\left[\beta_{0 t}, \beta_{1 t}, \beta_{2 t}\right]$ the timevarying parameters by using the Kalman filter method.

The data series used for the empirical study are: Romania private consumption \% in GDP, real GDP growth rate (INSSE data base), government expenditure \%GDP (EUROSTAT databases) and they cover the period 2004q2-2019q4.

The observed and computed $\Delta C_{t}$ using the resulted time-varying Kalman filter parameters, are represented below.

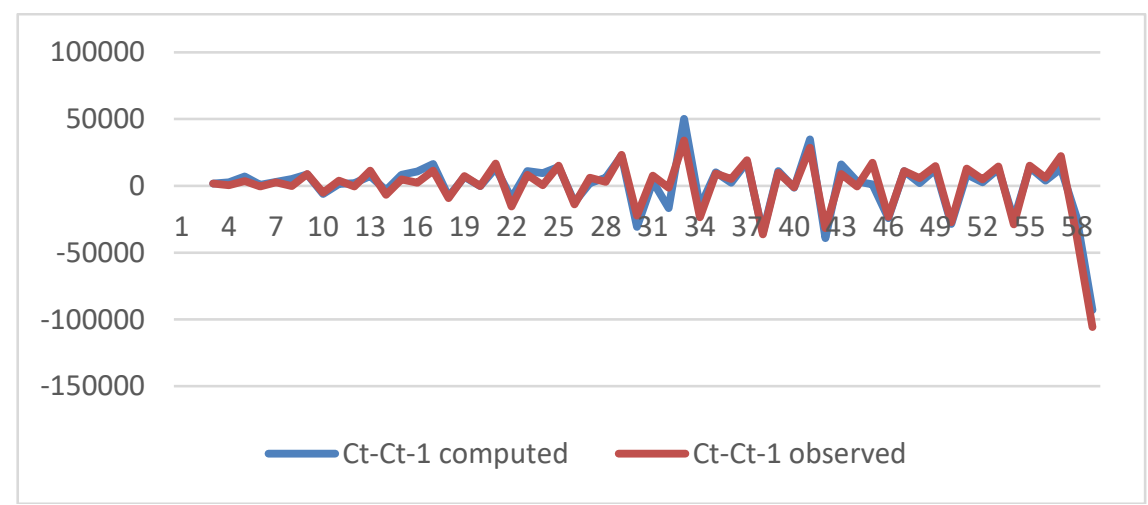

Figure 1. Final consumption growth observed and computed with KF time-varying coefficients

We note that the differences obtained between the computed and the observed values are small, proving a good fitting. The consumption function will be used in some additional models in order to check the existence of non- Keynesian effects of the fiscal policies.

The second model employed to investigate the consumption channel of non-Keynesian effects in Romania uses a version of the consumption function proposed by Rzońca and Ciżkowicz (2005).

$c_{t}=\mu+\gamma c_{t-1}+\sum_{i=1}^{2} \delta_{i} g d p_{t-1+1}+\sum_{k=1}^{2} \beta_{k} i m p_{t-1+1}+\sum_{m=1}^{2} \gamma_{m}$ reer $_{t-1+1}+\varepsilon_{t}$

In the model above $c_{t}$ is the growth rate of the private consumption, the other variables having the same meaning as above. The presence of the consumption channel non-Keynesian effects 
is proved if we have negative coefficient $\beta_{k}<0$ if at least for one $\mathrm{k}, k=1$ or 2 . The change rate of the fiscal impulse is computed using both primary balance measure and Blanchard measure (BFI).

In order to compute (BFI) we firstly make the assumption that the government expenditure rate is a function of the unemployment rate one period before $g_{t}\left(u_{t-1}\right)$.

In addition, we consider that $g_{t}\left(u_{t-1}\right)$ is a linear function and we compute the estimated function.

$g_{t}\left(u_{t-1}\right)=0.01724+0,34825 u_{t-1}+\varepsilon_{t}$.

In $(8)$ we note that the contribution of the unemployment rate to the government spending rate is important and valued 0,34825. The estimation uses the unemployment data from International Bureau of Labor, INSSE quarterly data, covering the period 2004q2-2019q4. The figures below reflect the fiscal impulse computed using the primary deficit and Blanchard methods for Romania.

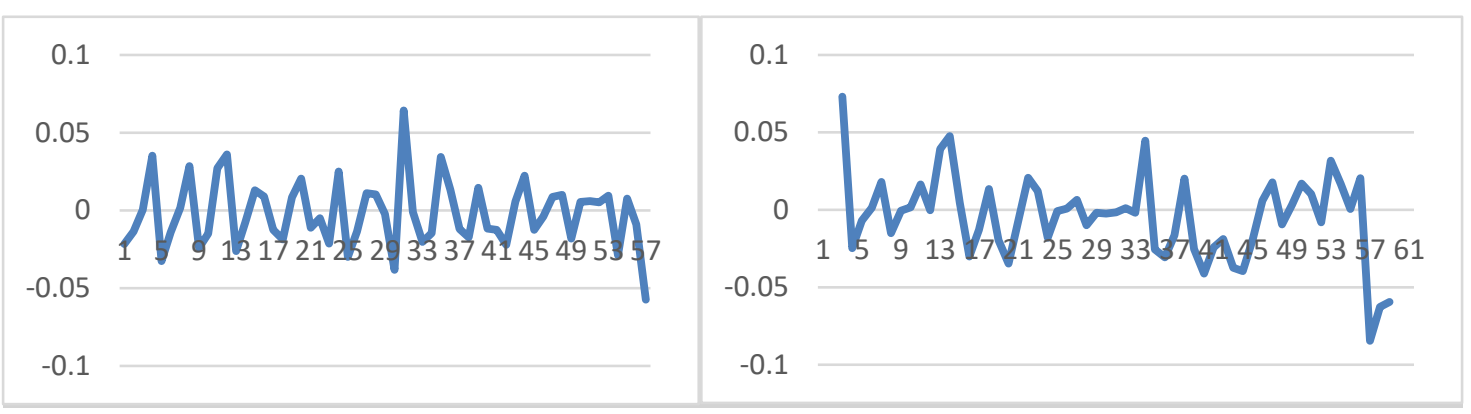

Figure 2. Primary Deficit Fiscal impulse

Figure 3. Blanchard Fiscal impulse

We notice that the fiscal impulse calculated as deviations of the primary balance, is very fluctuating and valued between -0.05 and 0.05 . On the other hand, (BFI) is less fluctuating, as expected, due to method of computing the government spending rate.

The data used to compute Rzońca and Ciżkowicz's consumption functions are: real interest rate (nominal interest rate minus inflation rate, National Bank of Romania data), fiscal impulse (both primary deficit and Blanchard measures), real final consumption rate data, real GDP growth rates, INS data 2004q2-2019q4.

The computed Rzońca and Ciżkowicz consumption function, using primary deficit fiscal impulse is given below.

$c_{t}=0,0726 c_{t-1}+0,49446 g d p_{t}+0,054 g d p_{t-1}-0,165129 \mathrm{imp}_{t}+$

$+0,261329$ imp $_{t-1}-2,36002$ reer $_{t}+2,630826$ reer $_{t-1}+\varepsilon_{t}$

We note that the contribution of the current GDP on the consumption is important, while the contribution of delayed real GDP is much lower, as expected.

We also note that the current fiscal impulse has a negative and quite significant contribution which reveals a possible non-Keynesian effect, while the influence of the delayed impulse is positive, marking a usual Keynesian effect.

The consumption and the real interest rate in the current period have opposite tendencies that could be the result of the speculative behavior of consumers to capitalize a part of their income on the money or financial market. The positive relationship between the consumption and the delayed real interest rate is the effect of consumption of wealth.

The computed Rzońca and Ciżkowicz's consumption functions using Blanchard fiscal impulse is given below. 


$$
\begin{aligned}
& c_{t}=0,27898 c_{t-1}+0,241026 g d p_{t}+0,02017 g d p_{t-1}-0,43226 i m p_{t}+ \\
& +0,29985 \text { impi }_{t-1}-2,62908 \text { reer }_{t}+3,078844 \text { reer }_{t-1}+\varepsilon_{t}
\end{aligned}
$$

We note that the dependences between consumption as dependent variable and the independent variables have the same directions though different weights.

There is a more significant non-Keynesian which is given by the negative coefficient of fiscal impulse in the current period. Also, the wealth effect of the real interest rate is more pronounced while the consumption from current income is much lower.

\section{References}

[1] R. Ahrend, P. A. Catte and R. Price, „Interactions between monetary and fiscal policy: How monetary conditions affect fiscal consolidation”, OECD Working Paper no.49, 2006.

[2] A. Alesina and S. Ardagna, „Tales of fiscal adjustments”, Economic Policy, vol. 13, no. 27, pp. 487-545, 1998.

[3] A. Alfonso and F. Silva Leal, "Fiscal Episodes in the EMU: Elasticities and non-Keynesian Effects", REM: Research in Economics and Mathematics, ISSN 2184-108X, 2019

[4] S. Ardagna, "Fiscal stabilizations: when do you work and why", European Economic Review, vol. 48, no.5, pp. 1047-1074, 2004.

[5] G. Bertola and A. Drazen, ,Trigger points and budget cuts: explaining the effects of fiscal austerity", American economic Review, vol. 83, no.1, pp.11-26, 1993.

[6] O. Blanchard, „Can severe fiscal contraction be expansionary? Tales of two small European countries", NBER Macroeconomics Annual, vol. 5, pp. 111-116, 1990.

[7] O. Blanchard and R. Perotti, „An empirical characterization of the dynamic effects of changes in government spending and taxes on output", The Quarterly Journal of Economics, vol. 117, no.4, pp.1329-1368, 2002.

[8] R. Canale, P. Foresti, U. Marani and O. Napolitano, „On keynessian effects of (apparent) non-keynessian fiscal policies", Facolta' di Economia. Universita' di Napoli "Federico II", MPRA, 2007.

[9] V. M.da Costa Carvalho, Non-Keynesian Effects of Fiscal Policy in a New-Keynesian General Equilibrium Model for the Euro Area, Doctoral Thesis, 2009.

[10] C. McDermott and R.F. Wescott, "An Empirical Analysis of Fiscal Adjustments", IMF Staff Papers, vol. 43, no. 4, pp. 725-935, 1996. Available: http://www.jstor.org/stable/3867367?origin=pubexport main text (application/pdf)

[11] A. Drazen, „Can severe fiscal contraction be expansionary? Tales of two small European countries”. NBER Macroeconomics Annual, vol. 5, pp.117-122, 1990.

[12] M. Feldstein, „Government deficits and aggregate demand”, Journal of Monetary Economics, vol. 9, no.1, pp. 1-20, 1982.

[13] F. Giavazzi and M. Pagano, „Can severe fiscal contraction be expansionary?Tales of two small European countries”, NBER Macroeconomic Annual, vol. 5, pp. 75-111, 1990.

[14] F. Giavazzi and M. Pagano, „Non-keynessian effects of fiscal policy changes: international evidence and the Swedish experience", Swedish Policy Review, vol. 3, no.1, pp. 67-103, 1996.

[15] F.Giavazzi, T. Iappelli and M. Pagano, ,Searching for non-keynesian effects of fiscal policy changes", CSEF Center for Studies in Economics and Finance, WP. no. 16, 1999.

[16] M. Neycheva , "Non-Keynesian Effects of Government Spendings: Some Implications for the Stability and Growth Pact", MPRA no. 5277, 2007.

[17] R. Perotti, „Fiscal policy in good times and bad”, The Quarterly Journal of Economics, vol. 114, no.4, pp.1399-1436, 1999. 
[18] A. Rzońca and P. Ciżkowicz, "Non-keynesian effects of fiscal contraction in new member states", European Central Bank, Working Paper Series no. 519, 2005.

[19] A. Tagkalakis, "Discretionary Fiscal Policy and Economic Activity of Greece", Bank of Greece, WP 169, 2013. Available: https://ideas.repec.org/p/bog/wpaper/169.html

[20] A. Sutherland, „Fiscal Crises and Aggregate Demand: Can High Public Debt Reverse the Effects of Fiscal Policy”, Journal of Public Economics, vol. 65, no.2, pp. 147-162, 1997.

[21] W. Yang, J. Fidmuc and S. Ghosh, „Macroeconomic effects of fiscal policy and fiscal adjustment: a tale of two approaches", Journal of International Money and Finance, vol. 57, pp. 31-60, 2015. 